\title{
The Effect of Gonadotropin-releasing Hormone Analog Treatment on Body Mass Index and Height in Female Patients with Central Precocious Puberty
}

\author{
(D) Muammer Büyükinan1', (1) Hüseyin Kurku² \\ ${ }^{1}$ Konya Training and Research Hospital, Clinic of Paediatric Endocrinology, Konya, Turkey \\ ${ }^{2}$ Konya Training and Research Hospital, Clinic of Biochemistry, Konya, Turkey
}

\begin{abstract}
Aim: Gonadotropin-releasing hormone agonists ( $\mathrm{GnRHa}$ ) are widely used in the treatment of central precocious puberty (CPP). There is concern that GnRHa treatment, whose positive effects on the adult height are known, may cause weight gain and body mass index (BMI) increase. The aim of this study was to assess the effect of the GnRHa treatment on BMI and height in female patients with CPP.

Materials and Methods: Ninety-two patients diagnosed with idiopathic CPP and 22 patients diagnosed with organic CPP, who received GnRHa treatment were included in the study. Data taken on the treatment start date, $6^{\text {th }}$ month, $1^{\text {st }}$ and $2^{\text {nd }}$ year for height, weight, BMI and bone age were obtained retrospectively from the file records.

Results: BMI standard deviation score (SDS) increased during the treatment period in all the patients. In the second year of $\mathrm{GnRHa}$ treatment, BMI SDS was higher in the organic CPP, compared to the idiopathic CPP $(0.66 \pm 0.84$ and $1.35 \pm 0.72, p=0.007)$. In both groups, at the beginning of GnRHa treatment, the BMI SDS increase was higher in those patients with normal weight compared to those who were overweight/ obese. In both groups, the prevalence of obesity was higher than the reference population at the beginning of treatment. An increase was determined in the height SDS and predicted adult height in both groups according to bone age.

Conclusion: In patients with CPP, the prevalence of obesity was higher in the first application compared to the reference population. In CPP, BMI SDS increased with GnRHa treatment. The weight of the patients at the beginning of the treatment affected the weight and BMI change with GnRHa treatment. Those patients with organic CPP were more prone to weight gain and BMI increase.
\end{abstract}

Keywords: Central precocious puberty, gonadotropin-releasing hormone analogues, obesity

\section{Introduction}

Precocious puberty (PP) is defined as the initiation of secondary sex characters before the age of eight in girls and nine in boys. PP may be true (central-gonadotropin dependent) or pseudo (peripheral-gonadotropin independent). Central PP (CPP) occurs with sex steroids released by the gonads as a result of an early activation of the hypothalamic-pituitary-gonadal (HPG) axis. Increased sex steroids cause an acceleration in pubertal progression, height increase and bone maturation and may lead to a reduced final adult height, early menarche, and psychological disorders (1). The purpose of treatment in CPP is to stop the progression of secondary sex characters by suppressing the HPG axis, to slow the skeletal maturation, to slow the bone epiphyseal closure, to increase adult height, and to benefit 
psychosocial well-being (2). For this purpose, gonadotropinreleasing hormone agonists ( $\mathrm{GnRHa}$ ) have been widely used for the treatment of CPP for more than 30 years. $\mathrm{GnRHa}$ treatment that effectively inhibits gonadotropin secretion is generally a reliable treatment in children (2). In longterm follow-up studies, it was shown to increase final adult height in children with CPP but it did not show significant changes in reproductive activity (3). Studies on the efficacy and the auxological effects of GnRHa treatment in CPP are mainly related to revealing adult height gain (4). The results in the studies conducted about the effect of $\mathrm{GnRHa}$ treatment on body weight are contradictory. While it is reported in some studies that $\mathrm{GnRHa}$ treatment is linked with body fat mass, body weight and body mass index (BMI) increases (4-10), it is reported not to be linked in other studies $(3,5,9,11,12)$. Even some studies reported that it was associated with a decrease in BMI $(12,13)$.

Nutrition and body fat mass during childhood are closely related to PP. Considering the increasing prevalence of obesity all over the world and the higher prevalence of PP in obese people compared to the normal population (14-17), the importance of the effects of GnRHa treatment used for PP on body weight is increasing day by day.

The aim of this study was to evaluate the effects of the $\mathrm{GnRHa}$ treatment on $\mathrm{BMI}$ and height in female patients with central PP.

\section{Materials and Methods}

In this study, the records of patients who were diagnosed with PP in the Konya Training and Research Hospital, Clinic of Paediatric Endocrinology Outpatient between 2010 and 2018 were retrospectively reviewed. The study was approved by the Necmettin Erbakan University Faculty of Medicine Local Ethics Committee (approval number: 2017/1100). Informed consent was obtained. A total of 114 female patients, who received $\mathrm{GnRHa}$ treatment and were in the age group of $1.65-8.9$ years, including 22 patients (19.3\%) followed up with the diagnosis of PP (organic CPP) associated with an organic disorder of central neural system and 92 patients $(80.7 \%)$ followed up with the diagnosis of idiopathic CPP were included in the study.

Idiopathic CPP criteria were taken as follows: 1) the onset of budding in the breasts before the age of 8 years in girls, 2) determination of at least 1 year advanced bone age compared to chronological age, 3 ) the peak luteinizing hormone (LH) $\geq 5$ $\mathrm{mIU} / \mathrm{mL}$ examined with chemiluminescence immunoassay method after the exogenous GnRH (gonadorelin $100 \mu \mathrm{g}$ ) intravenous injection, 4) a lack of a history suggesting a central nervous system disease and the presence of normal cranial magnetic resonance imaging (MRI) symptoms (18). Patients with a history of central nervous system disease and/or pathological cranial MRI symptoms were accepted as central PP (organic CPP) developing secondarily to central nervous system pathologies. Patients who used drugs that might affect anthropometric measures and had a systemic disease such as hypothyroidism, congenital adrenal hyperplasia or Cushing's disease were excluded from the study.

From the outpatient clinic file records of patients, their weight, height, puberty phase according to Marshall and Tanner (19), basal serum LH, follicle stimulating hormone $(\mathrm{FSH})$, and estradiol studied from venous blood samples taken between 08.00-12.00 after 12-hour fasting, peak serum LH level after exogenous GnRH (gonadorelin 100 $\mu \mathrm{g}$ ) intravenous injection, bone age assessment according to the Greulich and Pyle (20) method, and cranial imaging results were recorded. BMI of the patients was calculated with weight $(\mathrm{kg})$ - height $(\mathrm{cm})^{2}$ by using their weight and height measurements; height standard deviation score (SDS), BMI SDS, BMI percentile values were obtained using standardized data prepared for Turkish children based on age and gender (21). BMI $\geq 95$ percentile was considered as obese, 85-95 percentile as overweight, and $<85$ percentile as normal body weight. Predicted adult height (PAH) according to bone age was calculated according to the Bayley and Pinneau (22) method. Height SDS, BMI SDS, BMI percentile, and $\mathrm{PAH}$ value were calculated from the height, weight and bone age data for the $6^{\text {th }}$ month, $1^{\text {st }}$ year and $2^{\text {nd }}$ year of the treatment in the follow-up of patients.

In the routine protocol of the clinic of paediatric endocrinology outpatient; for the treatment of PP, GnRHa leuprolide (Lucrin $3.75 \mathrm{mg}$ depot) or triptorelin (Decapeptyl $3.75 \mathrm{mg}$ depot) is intramuscularly administered every 28 days with a dose of $3.75 \mathrm{mg}$ if the patient has a weight $>20 \mathrm{~kg}$ and with a dose of $1.875 \mathrm{mg}$ if the patient has a weight $<20 \mathrm{~kg}$ (2). Patients undergoing treatment are followed up with anthropometric measurements, pubertal symptoms, and serum LH levels every 3 months. During the follow-up, serum $\mathrm{LH}$ level $<3 \mathrm{mIU} / \mathrm{mL}$ at $60^{\text {th }}$ minute after $\mathrm{GnRHa}$ injection is accepted as suppressed HPG axis; serum LH level $\geq 3 \mathrm{mIU} / \mathrm{mL}$ is accepted as non-suppressed axis (23) and the axis is checked again in terms of suppression with a standard $\mathrm{GnRH}$ test in the $3^{\text {rd }}$ week of GnRHa injection. A peak $\mathrm{LH}$ level $<2 \mathrm{mlU} / \mathrm{mL}$ in the standard $\mathrm{GnRH}$ test is considered as suppressed HPG axis, while a peak $\mathrm{LH} \geq 2 \mathrm{mIU} / \mathrm{mL}$ is considered as non-suppressed axis (24) and GnRHa treatment dose is increased to $7.5 \mathrm{mg} / 28$ days. The data of the patients, who were followed up in this context and were diagnosed with central PP, and received $\mathrm{GnRHa}$ treatment, were included in the study. 
Serum LH, FSH, and estradiol levels were studied in the Biochemistry Laboratory of Konya Training and Research Hospital using an ADVIA Centaur XP (Siemens Healthcare Diagnostics, Camberley, UK) device with a chemiluminescence immunoassay method.

\section{Statistical Analysis}

For statistical analyses, the IBM SPSS Statistics version 22 (IBM Corporation, Armonk, NY, United States of America) program was used. The data were determined as mean \pm standard deviation and the significance limit for all statistics was accepted as $p<0.05$. In order to decide the appropriate test statistics in the evaluation of data, first the suitability of data to normal distribution was tested by applying Kolmogorov-Smirnov test statistics. In the numeric data, Student's t-test in two-group comparisons for the data meeting normal distribution; Mann-Whitney $U$ test for comparison of data that did not show normal distribution; ANOVA in the comparison of repeated measurements in the same group; chi-square and Fisher's exact tests in the comparison of qualitative data were used.

\section{Results}

The admission average age was $7.84 \pm 1.01$ years in the idiopathic CPP group and $7.57 \pm 1.03$ years in the organic CPP group. The bone age at the beginning of the treatment was $9.99 \pm 1.13$ years in the idiopathic CPP group and $9.44 \pm 1.5$ years in the organic CPP group. Admission age, age at beginning of treatment, bone age, bone age-age at beginning of treatment difference, basal LH, FSH, estradiol and peak $\mathrm{LH}$ responses to classical $\mathrm{GnRH}$ test were similar in the idiopathic and organic CPP groups (Table I).

The mean BMI SDS increased during treatment in all patients receiving GnRHa treatment. BMI SDS statistically

Table I. Characteristics of the patients before gonadotropinreleasing hormone agonists treatment

\begin{tabular}{|l|l|l|l|}
\hline & $\begin{array}{l}\text { Idiopathic } \\
\text { CPP, }(\mathbf{n = 9 2 )}\end{array}$ & $\begin{array}{l}\text { Organic } \\
\mathbf{C P P},(\mathbf{n = 2 2})\end{array}$ & $\begin{array}{l}\mathbf{p} \\
\text { value }\end{array}$ \\
\hline Admission age (year) & $7.84 \pm 1.01$ & $7.57 \pm 1.03$ & 0.201 \\
\hline Tb age (year) & $8.14 \pm 0.98$ & $7.79 \pm 1.15$ & 0.161 \\
\hline Bone age (year) & $9.99 \pm 1.30$ & $9.44 \pm 1.50$ & 0.203 \\
\hline$\triangle$ KY-Tb age (year) & $1.78 \pm 0.97$ & $1.72 \pm 0.92$ & 0.802 \\
\hline Basal FSH (IU/L) & $3.50 \pm 2.2$ & $3.69 \pm 2.2$ & 0.686 \\
\hline Basal LH (IU/L) & $0.70 \pm 0.9$ & $0.71 \pm 1.0$ & 0.909 \\
\hline Basal estradiol (pg/mL) & $29.5 \pm 23.1$ & $27.7 \pm 18.8$ & 0.956 \\
\hline Peak LH (IU/L) & $12.9 \pm 10.3$ & $13.8 \pm 6.7$ & 0.126 \\
\hline
\end{tabular}

Values are given as mean \pm standard deviation, CPP: Central precocious puberty, Tb: Gonadotropin-releasing hormone agonists treatment beginning, FSH: Follicle stimulating hormone, LH: Luteinizing hormone significantly increased in the $1^{\text {st }}$ year $(0.67 \pm 0.12$ and $0.88 \pm 0.12, p<0.001)$ and $2^{\text {nd }}$ year $(0.67 \pm 0.12$ and $0.89 \pm 0.11$, $\mathrm{p}=0.005$ ) compared to the beginning of treatment, in the $1^{\text {st }}$ year $(0.73 \pm 0.12$ and $0.88 \pm 0.12, p=0.014)$ and $2^{\text {nd }}$ year $(0.73 \pm 0.12$ and $0.89 \pm 0.11, p=0.023)$ compared to the $6^{\text {th }}$ month of treatment (Table II).

When examining the mean BMI SDS values of the patients in the groups, it was determined that there was a significant increase in BMI SDS in the $1^{\text {st }}$ year compared to the beginning of treatment in patients with idiopathic CPP $(0.63 \pm 0.88$ and $0.76 \pm 0.84, p=0.006)$. A significant increase was found in BMI SDS in the $2^{\text {nd }}$ year compared to the beginning of treatment in the organic CPP group $(0.80 \pm 0.97$ and $1.35 \pm 0.72, p=0.029)$. Although BMI SDS was not different between the two groups in the $6^{\text {th }}$ month and $1^{\text {st }}$ year of $\mathrm{GnRHa}$ treatment, BMI SDS was significantly higher in the organic CPP group compared to the idiopathic CPP group in the $2^{\text {nd }}$ year of the treatment $(0.66 \pm 0.84$ and $1.35 \pm 0.72, p=0.007$ ) (Table III).

In the patients who had normal weight at the beginning of GnRHa treatment in both groups, the BMI SDS increase

Table II. Average body mass index standard deviation score values of all patients in the beginning, $6^{\text {th }}$ month, $1^{\text {st }}$ year and $2^{\text {nd }}$ year of the treatment

\begin{tabular}{|c|c|}
\hline & $\begin{array}{l}\text { Idiopathic CPP+Organic } \\
\text { CPP }(n=114)\end{array}$ \\
\hline BMI SDS tb & $0.67 \pm 0.12$ \\
\hline BMI SDS $6^{\text {th }}$ month & $0.73 \pm 0.12$ \\
\hline BMI SDS $1^{\text {st }}$ year & $0.88 \pm 0.12^{a, c}$ \\
\hline BMI SDS $2^{\text {nd }}$ year & $0.89 \pm 0.11^{b, d}$ \\
\hline
\end{tabular}

CPP: Central precocious puberty, BMI: Body mass index, tb: GnRHa treatment beginning, ${ }^{a} p<0.001$ : First year BMI SDS change compared to the beginning of treatment, ${ }^{b} p=0.005$ : Second year BMI SDS change compared to the beginning of treatment, ${ }^{c} p=0.014$ : First year BMI SDS change compared to $6^{\text {th }}$ month of treatment, ${ }^{d} p=0.023$ : Second year BMI SDS change compared to $6^{\text {th }}$ month of treatment

Table III. Body mass index standard deviation score changes in patients in the follow-up before and after gonadotropinreleasing hormone agonists treatment

\begin{tabular}{|c|c|c|c|}
\hline & $\begin{array}{l}\text { Idiopathic } \\
\text { CPP, }(n=92)\end{array}$ & $\begin{array}{l}\text { Organic CPP, } \\
(n=22)\end{array}$ & p value ${ }^{\ddagger}$ \\
\hline BMI SDS tb & $0.63 \pm 0.88$ & $0.80 \pm 0.97$ & 0.077 \\
\hline BMI SDS $6^{\text {th }}$ month & $0.64 \pm 0.84$ & $1.01 \pm 0.91$ & 0.058 \\
\hline BMI SDS $1^{\text {st }}$ year & $0.76 \pm 0.84^{*}$ & $1.19 \pm 0.75$ & 0.057 \\
\hline BMI SDS $2^{\text {nd }}$ year & $0.66 \pm 0.84$ & $1.35 \pm 0.72^{\dagger}$ & 0.007 \\
\hline
\end{tabular}

CPP: Central precocious puberty, BMI: Body mass index, SDS: Standard deviation score, tb: Gonadotropin-releasing hormone agonists treatment beginning, ${ }^{*} p=0.006$ : First year BMI SDS change compared to the beginning of treatment; ${ }^{\dagger} p=0.029$ : Second year BMI SDS change compared to the beginning of treatment, ${ }^{\ddagger}$ statistical difference between groups 
was higher in these patients compared to overweight-obese ones. BMI SDS at the beginning of treatment in patients who had a normal weight at the beginning of treatment in the idiopathic CPP group significantly increased in the $1^{\text {st }}$ year $(0.02 \pm 0.57$ and $0.26 \pm 0.66, p=0.008)$ and $2^{\text {nd }}$ year $(0.02 \pm 0.57$ and $0.28 \pm 0.65, p=0.011)$ of the treatment. Likewise, BMI SDS at the beginning of treatment in patients who had a normal weight at the beginning of treatment in the organic CPP group significantly increased in the $1^{\text {st }}$ year $(0.02 \pm 0.56$ and $0.36 \pm 0.36, p=0.048)$ and $2^{\text {nd }}$ year $(0.02 \pm 0.56$ and $0.63 \pm 0.43, p=0.03)$ of $\mathrm{GnRHa}$ treatment. No significant change was observed in the BMI SDS during treatment of those patients who were overweight-obese at the beginning of $\mathrm{CnRHa}$ treatment in both groups (Table IV).

While $34 \%$ of the patients in the idiopathic CPP group were overweight- obese $(21 \%, 13 \%)$ at the beginning of the treatment, this rate was determined as $45 \%$ (25\%, $20 \%$ ) in the organic CPP group. An increase was observed in the frequency of overweight-obese patients undergoing GnRHa treatment in the organic CPP group (50\%, 59\%, and $64 \%$, respectively in the $6^{\text {th }}$ month, $1^{\text {st }}$ year, and $2^{\text {nd }}$ year of treatment). The frequency of obese patients with $\mathrm{BMI}>95$ percentile was higher in the organic CPP group compared to the idiopathic CPP group both in the $1^{\text {st }}$ year (47\% and $18 \%$, $\mathrm{p}=0.039)$ and $2^{\text {nd }}$ year $(57 \%$ and $19 \%, p=0.02)$ of $\mathrm{CnRHa}$ treatment (Figure 1).

In patients with idiopathic CPP, the $2^{\text {nd }}$ year height SDS was significantly lower compared to the beginning of treatment $(1.05 \pm 1.03$ and $0.74 \pm 1.06, p=0.024)$; whereas, height SDS according to bone age was significantly higher in the $2^{\text {nd }}$ year compared to the beginning of treatment $(-1.01 \pm 0.95$ and $-0.68 \pm 0.72, p=0.03)$. Similarly, the height SDS of patients with organic CPP was significantly higher based on bone age compared to the beginning of treatment $(-1.19 \pm 0.82$ and $-0.69 \pm 0.68, p=0.025)$. No difference was found in the height SDS in the organic CPP group in the $1^{\text {st }}$ and $2^{\text {nd }}$ years compared to the beginning of treatment.

PAH was determined as $158.7 \pm 6.5,162.3 \pm 6.1$, and $164.4 \pm 6.6$ $\mathrm{cm}$, respectively for the beginning, $1^{\text {st }}$ year and $2^{\text {nd }}$ year of treatment ( $p>0.05)$ in patients with idiopathic CPP; and as $159.9 \pm 6.1,161 \pm 5.3$, and $164.7 \pm 4.6 \mathrm{~cm}$, respectively ( $p>0.05$ ) in the organic CPP group. There was no significant difference between the two groups in terms of $1^{\text {st }}$ and $2^{\text {nd }}$ year $\mathrm{PAH}$. $\triangle \mathrm{PAH}$ was determined to be on average $5.7 \mathrm{~cm}$ in the idiopathic CPP group and $4.8 \mathrm{~cm}$ in the organic CPP group following 2 years of $\mathrm{GnRH}$ a treatment. No difference was determined in both groups in terms of $\triangle \mathrm{PAH}$ (Table V).

The average treatment durations were $2.8 \pm 0.84$ and $2.62 \pm 0.51$ years, respectively for the patients with idiopathic CPP and organic CPP ( $p>0.05)$. In both groups, $65 \%$ of the patients were using leuprolide and $35 \%$ were using triptorelin and there was no difference between the groups in terms of the frequency of medication usage. Cranial imaging was performed in 104 patients from 114 patients included in the study and pathological findings were determined in 22 of them (organic CPP). Pathologies detected in cranial imaging were: septum pellucidum anomaly $(n=1)$, hypothalamic

Idiopathic CPP

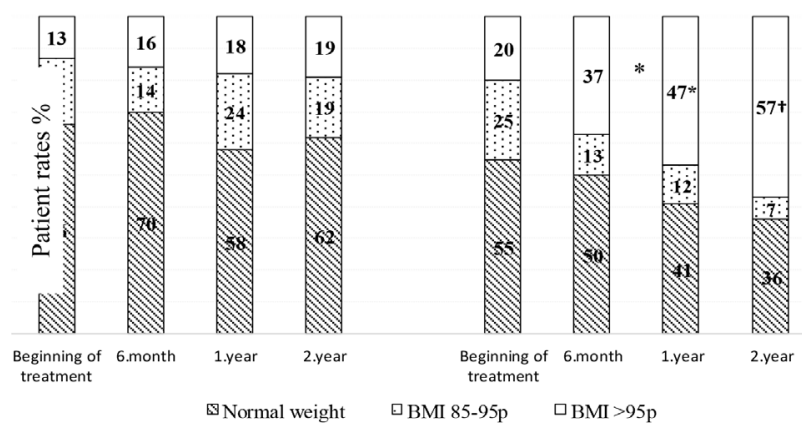

Figure 1. Overweight, obese patient rates and changes in the beginning, $6^{\text {th }}$ month, $1^{\text {st }}$ year and $2^{\text {nd }}$ year of $\mathrm{GnRHa}$ treatment in patient groups with idiopathic and organic CPP. ${ }^{*} p=0.039$ : Difference between the $1^{\text {st }}$ year $\mathrm{BMI}>95 \mathrm{p}$ patient rates between two groups, ${ }^{\dagger} \mathrm{p}$ : 0.02: Difference between the $2^{\text {nd }}$ year $\mathrm{BMI}>95 \mathrm{p}$ patient rates between two groups CPP: Central precocious puberty, BMI: Body mass index

Table IV. Body mass index standard deviation score changes with treatment in patients who were normal weight and overweight-obese before the gonadotropin-releasing hormone agonists treatment

\begin{tabular}{|c|c|c|c|c|}
\hline & \multicolumn{2}{|c|}{ Idiopathic CPP } & \multicolumn{2}{|c|}{ Organic CPP } \\
\hline & BMI $\geq 85 p,(n=61)$ & Normal BMI, $(n=31)$ & BMI $\geq 85 p,(n=12)$ & Normal BMI, $(n=10)$ \\
\hline BMI SDS tb & $1.49 \pm 0.37$ & $0.02 \pm 0.57$ & $1.70 \pm 0.45$ & $0.02 \pm 0.56$ \\
\hline BMI SDS $6^{\text {th }}$ month & $1.40 \pm 0.59$ & $0.14 \pm 0.62$ & $1.76 \pm 0.45$ & $0.13 \pm 0.49$ \\
\hline BMI SDS $1^{\text {st }}$ year & $1.58 \pm 0.54$ & $0.26 \pm 0.66^{*}$ & $1.82 \pm 0.22$ & $0.36 \pm 0.36^{\dagger}$ \\
\hline BMI SDS $2^{\text {nd }}$ year & $1.47 \pm 0.56$ & $0.28 \pm 0.65+$ & $1.89 \pm 0.24$ & $0.63 \pm 0.43^{\ddagger}$ \\
\hline
\end{tabular}

CPP: Central precocious puberty, BMI: Body mass index, SDS: Standard deviation score, tb: Gonadotropin-releasing hormone agonists treatment onset, ${ }^{*} \mathrm{p}=0.008$ : First year BMI SDS change compared to the beginning of treatment; ${ }^{+} p=0.011$ : Second year BMI SDS change compared to the beginning of treatment; ${ }^{\dagger} p=0.048$ : First year $B M I$ SDS change compared to the beginning of treatment; ${ }^{\ddagger} p=0.03$ : Second year BMI SDS change compared to the beginning of treatment 
Table V. Height standard deviation score and predicted adult height values of patients in the follow-up before and after gonadotropin-releasing hormone agonists treatment

\begin{tabular}{|c|c|c|c|}
\hline & $\begin{array}{l}\text { Idiopathic } \\
\text { CPP, }(n=92)\end{array}$ & $\begin{array}{l}\text { Organic CPP } \\
(n=22)\end{array}$ & p value $\ddagger$ \\
\hline Height SDS tb & $1.05 \pm 1.03$ & $0.92 \pm 1.04$ & 0.572 \\
\hline Height SDS $1^{\text {st }}$ year & $1.01 \pm 0.98$ & $1.02 \pm 1.05$ & 0.427 \\
\hline Height SDS $2^{\text {nd }}$ year & $0.74 \pm 1.06^{*}$ & $1.06 \pm 0.87$ & 0.314 \\
\hline $\begin{array}{l}\text { Height SDS tb } \\
\text { compared to } K Y\end{array}$ & $-1.01 \pm 0.95$ & $-1.19 \pm 0.82$ & 0.420 \\
\hline $\begin{array}{l}\text { Height SDS } 1^{\text {st }} \text { year } \\
\text { compared to KY }\end{array}$ & $-0.83 \pm 0.85$ & $-0.87 \pm 0.85$ & 0.250 \\
\hline $\begin{array}{l}\text { Height SDS } 2^{\text {nd }} \text { year } \\
\text { compared to KY }\end{array}$ & $-0.68 \pm 0.72^{\dagger}$ & $-0.69 \pm 0.68^{+}$ & 0.400 \\
\hline PAH tb $(\mathrm{cm})$ & $158.7 \pm 6.5$ & $159.9 \pm 6.1$ & 0.434 \\
\hline $\mathrm{PAH} 1^{\text {st }}$ year $(\mathrm{cm})$ & $162.3 \pm 6.1$ & $161 \pm 5.3$ & 0.505 \\
\hline $\mathrm{PAH} 2^{\text {nd }}$ year $(\mathrm{cm})$ & $164.4 \pm 6.6$ & $164.7 \pm 4.6$ & 0.066 \\
\hline$\triangle \mathrm{PAH} 2^{\text {nd }}$ year-tb $(\mathrm{cm})$ & 5.7 & 4.8 & 0.150 \\
\hline
\end{tabular}

CPP: Central precocious puberty SDS: Standard deviation score, tb: Gonadotropin-releasing hormone agonists treatment beginning, $\mathrm{PAH}$ : Predicted adult height, $\triangle \mathrm{PAH}$ : PAH difference; ${ }^{*} \mathrm{p}=0.024$ : Second year height SDS difference compared to the beginning of treatment, ${ }^{\dagger} p=0.03$ : Height SDS according to $2^{\text {nd }}$ year $\mathrm{KY}$ compared to the beginning of treatment, ${ }^{+} p=0.025$ : Height SDS according to $2^{\text {nd }}$ year KY compared to the beginning of treatment, ‡difference between two groups

hamartoma $(H H)(n=3)$, arachnoid cyst $(n=5)$, porencephalic cyst $(n=3)$, hydrocephalus/ventriculo-peritoneal shunt $(n=5)$, periventricular leukomalacia-hypoxic ischemic encephalopathy sequelae $(n=3)$, neuroepithelial cyst $(n=1)$, and cerebral cortical atrophy $(n=1)$.

\section{Discussion}

This study investigated the effect of GnRHa treatment on body weight and height in female patients suffering from central PP for both idiopathic and organic reasons.

The present study revealed that $\mathrm{GnRHa}$ treatment in patients with CPP caused an increase in BMI SDS, that patients with organic CPP were more prone to the increase in weight and BMI, and the patients had height gain after undergoing the GnRHa treatment.

In the literature, the results of studies evaluating the effects of $\mathrm{GnRHa}$ treatment on body weight and BMI are controversial and incompatible with each other. There are studies reporting that $\mathrm{GnRHa}$ treatment is linked with body weight, BMI and BMI SDS increases in patients with CPP $(4,6,9,10,25-29)$, whereas with other studies, GnRHa treatment is not linked with them $(3,5,9,11,12,30-33)$, and even GnRHa treatment decreases BMI $(12,13)$. The reason for the inconsistency between studies is not clear.
Possible causes may include different designs of studies, heterogeneous etiology including idiopathic and organic etiology, different gender and age ranges, different body weights at the beginning of $\mathrm{GnRHa}$ treatment, different treatment strategies, and different follow-up intervals. In a recent study conducted in Spain to evaluate BMI SDS of 333 patients with CPP who received GnRHa treatment, a significant increase was determined in BMI SDS during treatment and this increase was reported to continue after the interruption of the $\mathrm{GnRHa}$ treatment and reaching adult height (10). Similarly, in the present study, the average BMI SDS of all our patients who received GnRHa treatment increased both in the $1^{\text {st }}$ and $2^{\text {nd }}$ years compared to the beginning of treatment and in the $1^{\text {st }}$ and $2^{\text {nd }}$ years compared to the $6^{\text {th }}$ month (Table II). These results suggest that $\mathrm{GnRHa}$ treatment is associated with an increase in BMI and weight gain. The mechanism of GnRHa treatment causing an increase in body weight and BMI is not exactly known. There is a need for further studies on this subject that will explain the mechanism and evaluate adipokine levels involved in the energy-gonad axis such as leptin, neuropeptide $Y$, insulin and ghrelin.

In the present study, $1^{\text {st }}$ year BMI SDS in the idiopathic CPP group and $2^{\text {nd }}$ year BMI SDS in the organic CPP group showed a significant increase compared to the beginning of treatment. In the organic CPP group, the $2^{\text {nd }}$ year average BMI SDS values were higher than the idiopathic CPP group $(0.66 \pm 0.84$ and $1.35 \pm 0.72, p=0.007)$ (Table III). These results revealed that GnRHa treatment caused an increase in weight and BMI in patients with both idiopathic CPP and organic CPP and the weight gain and prevalence of overweight-obesity were higher in the organic CPP group compared to the idiopathic CPP group. In the literature, there are a limited number of studies comparing the effects of $\mathrm{GnRHa}$ treatment on body weight and $\mathrm{BMI}$ in idiopathic and organic CPP groups. Feuillan et al. (26) reported in their study conducted with 18 patients with CPP caused by hypothalamic hamartoma $\mathrm{HH}-\mathrm{CPP}$ and 32 patients with idiopathic CPP who received GnRHa treatment that BMI SDS was higher in patients with $\mathrm{HH}$-CPP compared to the idiopathic CPP group at the beginning of the treatment, termination of the treatment and during the follow-up period after the treatment. In another study conducted to evaluate the patients with $\mathrm{HH}-\mathrm{CPP}$ who received $\mathrm{GnRH}$ a treatment, the prevalence of overweight and obesity was reported to be high in female patients with $\mathrm{HH}-\mathrm{CPP}$ (34). The structural central disorder causing organic pathology in patients with organic CPP is likely to cause more weight gain by causing changes in the neuronal network of the central nervous system 
associated with obesity and in neurotransmitters. There is a need for more related studies which include more organic CPP and control groups.

In addition to the studies reporting that the increase in BMI SDS and obesity prevalence for patients receiving $\mathrm{GnRHa}$ treatment is observed in those children who were overweight before the treatment $(5,35)$, there are also other studies reporting that the patients who had normal weight at the beginning of treatment had more weight gain with $\mathrm{GnRHa}$ treatment compared to the overweightobese patients $(11,36,37)$. In the present study, a significant increase was observed in BMI SDS in both the $1^{\text {st }}$ year and $2^{\text {nd }}$ year of the treatment in patients who had normal weight at the beginning of treatment in both groups (Table IV). No significant change was observed in BMI SDS during the treatment period in those patients who were overweightobese at the beginning of treatment in both groups. The present study showed that patients who had a normal weight at the beginning of treatment had the tendency to have more weight gain during the treatment and the weight at the beginning of the treatment affected the weight gain associated with $\mathrm{GnRHa}$ treatment. The fact that the patients who were overweight and obese at the beginning of the treatment, and their parents, were more susceptible to the possible weight gain that could develop with the treatment and so had the tendency to take measures such as diet, physical activity, and sleep regulation to prevent obesity is believed to contribute to the lower weight gain in this group.

According to the Cosi-Tur 2016 study conducted by the Ministry of Health (38), it was found that the prevalence of overweight and obesity was $24.2 \%$ in girls who were aged between 6-9 years in Turkey, the prevalence of overweight and obesity was higher with the rate of $34 \%$ in the idiopathic CPP group and $45 \%$ in the organic CPP group compared to the reference age group in our patients who were in a similar age group at the beginning of their treatment (Figure 1). Similar to the results of the present study, Anık et al. (35) reported that the overweight prevalence and obesity prevalence in patients with PP before GnRHa treatment were higher than the average of the population with rates of $37.5 \%$ and $21.9 \%$, respectively. The high obesity prevalence determined at the beginning of $\mathrm{GnRH}$ a treatment in the present study shows a correlation between the obesity and PP.

In the literature, the results reporting on the prevalence of overweight-obesity in the follow-ups of GnRHa treatment in patients with CPP are contradictory similar to BMI and BMI SDS results $(11,12,35)$. In the present study, the rate of overweight-obese patients in the idiopathic CPP group which was $34 \%$ before the treatment, increased by $42.2 \%$ in the $1^{\text {st }}$ year and by $38 \%$ in the $2^{\text {nd }}$ year but it was not found to be statistically significant. In the organic CPP group, the prevalence of overweight-obese patients showed a significant increase at the beginning, the $1^{\text {st }}$ year, and the $2^{\text {nd }}$ year of the treatment with $45 \%, 59 \%$ and $64 \%$, respectively. The rate of overweight-obese patients was found to be higher in the $1^{\text {st }}$ and $2^{\text {nd }}$ year of the treatment in the organic CPP group compared to the idiopathic CPP group (Figure 1). Especially cases with organic CPP receiving GnRHa treatment should be monitored more carefully in terms of weight gain and risk factors that may contribute to weight gain should be eliminated during the follow-up.

In the present study, while height SDS did not change in the idiopathic and organic CPP groups in the $1^{\text {st }}$ year of $\mathrm{GnRHa}$ treatment, it decreased in the $2^{\text {nd }}$ year of treatment in the idiopathic group compared to the basal. In both groups, an increase was observed in height SDS according to bone age (Table V). Similarly, Weise et al. (39) reported that height SDS decreased according to age and height SDS increased according to bone age in 100 female patients with CPP receiving GnRHa treatment. Slowness in the rapid height increase, decrease in height SDS according to age and increase in height SDS according to bone age as a result of the rapid bone maturation stopping with $\mathrm{GnRHa}$ treatment are expected results and reflect the positive effect of this treatment on the height prognosis.

There are no randomized controlled studies evaluating the efficacy of $\mathrm{GnRH}$ a treatment in terms of height gain and most studies are conducted by comparing final height and the height before PAH treatment (4). Klein et al. (40) showed that a gain in adult height was achieved with basal $\mathrm{PAH}$ $149.3 \pm 9.6 \mathrm{~cm}$, final height $159.8 \pm 7.6 \mathrm{~cm}$ compared to pretreatment $\mathrm{PAH}$ in patients with PP receiving a 2-year $\mathrm{CnRHa}$ treatment and the height prognosis was affected positively by treatment. In the present study, an average of $5.7 \mathrm{~cm}$ height gain in the idiopathic CPP group and $4.8 \mathrm{~cm}$ height gain in the organic CPP group were obtained with a 2-year $\mathrm{GnRHa}$ treatment, which is compatible with the literature (Table V). It was thought that GnRHa treatment was effective in terms of height gain in patients with CPP with the height SDS and PAH increase according to bone age.

\section{Study Limitations}

The limitations of the present study are that the study was retrospective, the number of patients was low especially in the organic CPP group, there was no control group, it included a relatively short duration of treatment, and there was a lack of follow-up after the completion of the treatment. There is a need for prospective studies which also include serum adipokine levels for the interpretation of 
weight changes associated with $\mathrm{GnRH}$ a treatment including more patients and control groups.

\section{Conclusion}

The prevalence of obesity was higher in patients with CPP during the admission, and obesity is a risk factor for PP. BMI SDS increases with GnRHa treatment in CPP. Patients with organic CPP are more prone to weight and BMI increase. Patients with CPP receiving GnRHa treatment should be followed up for weight gain and obesity development and necessary precautions should be taken.

\section{Ethics}

Ethics Committee Approval: The study was approved by the Necmettin Erbakan University Faculty of Medicine Local Ethics Committee (approval number: 2017/1100).

Informed Consent: Informed consent was obtained.

Peer-review: Externally peer-reviewed.

\section{Authorship Contributions}

Surgical and Medical Practices: M.B., Concept: M.B., Design: M.B., Data Collection or Processing: M.B., H.K., Analysis or Interpretation: M.B., H.K., Literature Search: M.B., H.K., Writing: M.B.

Conflict of Interest: No conflict of interest was declared by the authors.

Financial Disclosure: The authors declared that this study received no financial support.

\section{References}

1. Berberoğlu M. Precocious puberty and normal variant puberty: Definition, etiology, diagnosis and current management. J Clin Res Pediatr Endocrinol 2009;1:164-74.

2. Heger S, Sippell WG, Partsch C). Gonadotropin-releasing hormone analogue treatment for precocious puberty. Twenty years of experience. Endocr Dev 2005;8:94-125.

3. Heger S, Partsch C), Sippell WG. Long-term outcome after depot gonadotropin-releasing hormone agonist treatment of central precocious puberty: final height, body proportions, body composition, bone mineral density, and reproductive function. ) Clin Endocrinol Metab 1999;84:4583-89.

4. Lee SJ, Yang EM, Seo /Y, Kim C). Effects of gonadotropin-releasing hormone agonist therapy on body mass index and height in girls with central precocious puberty. Chonnam Med I 2012;48:27-31.

5. Palmert MR, Mansfield MJ, Crowley WF Jr, Crigler JF Jr, Crawford JD, Boepple PA. Is obesity an outcome of gonadotropin releasing hormone agonist administration? Analysis of growth and body composition in 110 patients with central precocious puberty. I Clin Endocrinol Metab 1999;84:4480-88.

6. Aguiar AL, Couto-Silva AC, Vicente E), Freitas IC, Cruz T, Adan L. Weight evolution in girls treated for idiopathic central precocious puberty with $\mathrm{GnRH}$ analogues. I Pediatr Endocrinol Metab 2006;19:1327-34.

7. Boot AM, De Muinck Keizer,Schrama S, Pols HA, Krenning EP, Drop SL. Bone mineral density and body composition before and during treatment with gonadotropin releasing hormone agonist in children with central precocious and early puberty. I Clin Endocrinol Metab 1998;83:370-3.

8. Traggiai C, Perucchin PP, Zerbini K, Gastaldi R, De Biasio P, Lorini R. Outcome after depot gonadotrophin-releasing hormone agonist treatment for central precocious puberty: Effects on body mass index and final height. Eur I Endocrinol 2005;153:463-4.

9. Ko JH, Lee HS, Lim JS, Kim SM, Hwang JS. Changes in bone mineral density and body composition in children with central precocious puberty and early puberty before and after one year of treatment with $\mathrm{GnRH}$ agonist. Horm Res Paediatr 2011;75:174-9.

10. Corripio R, Soriano-Guillén L, Herrero F), et al. Changes in Body Mass Index in Girls with Idiopathic Central Precocious Puberty under Gonadotropin-Releasing Hormone Analogue Therapy: The Spanish Registry. Horm Res Paediatr 2016;86:154-60.

11. Kim SW, Kim YB, Lee JE, et al. The influence of gonadotropin releasing hormone agonist treatment on the body weight and body mass index in girls with idiopathic precocious puberty and early puberty. Ann Pediatr Endocrinol Metab 2017;22:95101.

12. Arrigo T, De Luca F, Antoniazzi F, et al. Reduction of baseline body mass index under gonadotropin suppressive therapy in girls with idiopathic precocious puberty. Eur / Endocrinol 2004;150:533-7.

13. Van der Sluis IM, Boot AM, Krenning EP, Drop SL, de Muinck Keizer-Schrama SM. Longitudinal follow-up of bone density and body composition in children with precocious or early puberty before, during and after cessation of $\mathrm{GnRH}$ agonist therapy. I Clin Endocrinol Metab 2002;87:506-12.

14. Lee HS, Yoon JS, Roh JK, Hwang JS. Changes in body mass index during gonadotropin-releasing hormone agonist treatment for central precocious puberty and early puberty. Endocrine 2016;54:497-503.

15. Dunger DB, Ahmed ML, Ong KK. Effects of obesity on growth and puberty. Best Pract Res Clin Endocrinol Metab 2005;19:37590.

16. Karlberg J. Secular trends in pubertal development. Horm Res 2002;57:19-30.

17. Troiano RP, Flegal KM. Overweight prevalence among youth in the United States: why so many different numbers? Int I Obes Relat Metab Disord 1999;23:22-7.

18. Carel JC, Eugster EA, Rogol A, et al. Consensus statement on the use of gonadotropin-releasing hormone analogs in children. Pediatrics 2009;123:e752-62.

19. Marshall W, Tanner J. Variations in pattern of pubertal changes in girls. Arch Dis Child 1969;44:291-303.

20. Greulich WW, Pyle SI. Radiographic Atlas of Skeletal Development of the Hand and the Wrist, ed 2. Stanford, Stanford University Press, 1959.

21. Neyzi O, Bundak R, Gökçay G, et al. Reference values for weight, height, head circumference, and body mass index in Turkish children. J Clin Res Pediatr Endocrinol 2015;7:280-93.

22. Bayley N, Pinneau SR. Tables for predicting adult height from skeletal age: revised for use with Greulich and Pyle standards. I Pediatr 1952;40:432-41.

23. Bhatia S, Neely EK, Wilson DM. Serum luteinizing hormone rises within minutes after depot leuprolide injection: implications for monitoring therapy. Pediatrics 2002;109:E30.

24. Lawson, M.L. \& Cohen, N. A single sample subcutaneous luteinizing hormone (LH)-releasing hormone (LHRH) stimulationtest for monitoring LH suppression in children with 
central precocious puberty receiving LHRH agonists. Journal of Clinical Endocrinology and Metabolism 1999;84:4536-40.

25. Oostdijk W, Rikken B, Schreuder S, et al. Final height in central precocious puberty after long term treatment with a slow release GnRH agonist. Arch Dis Child 1996;75:292-97.

26. Feuillan PP, Jones JV, Barnes K, Oerter Klein K, Cutler GB Ir. Reproductive axis after discontinuation of gonadotropin-releasing hormone analog treatment of girls with precocious puberty: Long term follow-up comparing girls with hypothalamic hamartoma to those with idiopathic precocious puberty. I Clin Endocrinol Metab 1999;84:44-9.

27. Antoniazzi F, Zamboni G, Bertoldo F, et al. Bone mass at final height in precocious puberty after gonadotropin-releasing hormone agonist with and without calcium supplementation. I Clin Endocrinol Metab 2003;88:1096-101.

28. Pasquino AM, Pucarelli I, Accardo F, Demiraj V, Segni M, Di Nardo R. Long-term observation of 87 girls with idiopathic central precocious puberty treated with gonadotropinreleasing hormone analogs: impact on adult height, body mass index, bone mineral content, and reproductive function. I Clin Endocrinol Metab 2008;93:190-95.

29. Chiumello G, Brambilla P, Guarneri MP, Russo G, Manzoni $P$, Sgaramella P. Precocious puberty and body composition: effects of $\mathrm{GnRH}$ analog treatment. J Pediatr Endocrinol Metab 2000;13:791-94.

30. Chiocca E, Dati E, Baroncelli Gl, et al. Body mass index and body composition in adolescents treated with gonadotropin releasing hormone analogue triptorelin depot for central precocious puberty: Data at near final height. Neuroendocrinology 2009;89:441-47.

31. Messaaoui A, Massa G, Tenoutasse S, Heinrichs C. Treatment of central precocious puberty with gonadotropinreleasing hormone agonist (triptorelin) in girls: breast development,skeletal maturation, height and weight evolution during and after treatment. Rev Med Brux 2005;26:27-32.
32. Gtab E, Barg E, Wikiera B, Grabowski M, Noczyńska A. Influence of $\mathrm{GnRH}$ analog therapy on body mass in central precocious puberty. Pediatr Endocrinol Diabetes Metab 2009;15:7-11.

33. Lazar L, Kauli R, Pertzelan A, Phillip M. Gonadotropinsuppressive therapy in girls with early and fast puberty affects the pace of puberty but not total pubertal growth or final height. J Clin Endocrinol Metab 2002;87:2090-94.

34. Ramos CO, Latronico AC, Cukier P, et al. Long-Term Outcomes of Patients with Central Precocious Puberty due to Hypothalamic Hamartoma after GnRHa Treatment: Anthropometric, Metabolic, and Reproductive Aspects. Neuroendocrinology 2018;106:203-10.

35. Anık A, Çatlı G, Abacı A, Böber E. Effect of gonadotropinreleasing hormone agonist therapy on body mass index and growth in girls with idiopathic central precocious puberty. Indian J Endocrinol Metab 2015;19:267-71.

36. Wolters B, Lass N, Reinehr T. Treatment with gonadotropin releasing hormone analogues: different impact on body weight in normal-weight and overweight children. Horm Res Paediatr 2012;78:304-11.

37. Arcari AJ, Gryngarten MG, Freire AV, et al. Body mass index in girls with idiopathic central precocious puberty during and after treatment with $\mathrm{GnRH}$ analogues. Int J Pediatr Endocrinol 2016;2016:15.

38. Türkiye Çocukluk Çağı (ilkokul 2. Sınıf Öğrencileri) Şişmanlık Araştırması, Cosı-Tur 2016. Sağlık Bakanlığı yayınları, Ankara 2017

39. Weise M, Flor A, Barnes KM, Cutler GB Jr, Baron J. Determinants of growth during gonadotropin-releasing hormone analog therapy for precocious puberty. I Clin Endocrinol Metab 2004;89:103-7.

40. Klein KO, Barnes KM, Jones JV, Feuillan PP, Cutler GB Jr. Increased final height in precocious puberty after long-term treatment with LHRH agonists: the National Institutes of Health experience. / Clin Endocrinol Metab 2001;86:4711-6. 